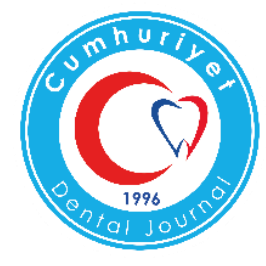

\title{
EVALUATION OF CARABELLI'S TRAIT IN A GROUP OF TURKISH PATIENTS
}

\author{
Bir Grup Türk Hastada Karabelli Özelliğinin Değerlendirilmesi
}

\author{
Mağrur KAZAK
}

\begin{abstract}
Makale Kodu/Article Code : :414992
Makale Gönderilme Tarihi $\quad: 13.04 .2018$

Kabul Tarihi $: 06.08 .2018$
\end{abstract}

\section{ABSTRACT}

Purpose: Dental morphological characteristics are useful for providing information in phylogenic and genetic studies and also for understanding variations within and among species. Carabelli cusp is expressed in several degrees and in different frequencies among humans; thus, it is helpful in comparing and characterizing populations. The objective of this retrospective study was to evaluate Carabelli's trait (CT) in a group of Turkish patients.

Materials and Methods: In this study, 213 patients between age of 14-65 (mean age $29.99 \pm 10.04$ ) were analyzed retrospectively according to presence or absence of CT on permanent maxillary first and second molars. All data were statistically analyzed using the IBM SPSS version 22 program (IBM SPSS, Turkey) and the chisquared test; $p<0.05$ was considered as statistically significant.

Results: Prevalence of CT was found to be $47.9 \%$ in the selected Turkish group. Incidence of CT in any of the teeth on \#16/26 was $46.9 \%$ and $4.2 \%$ on \#17/27. Incidence was detected more on \#26 (43.2\%) than on \#16 (40.4\%). Bilateral presence of CT on \#16/26 was detected in $78 \%$. CT was seen in $50.7 \%$ of females and in $42.9 \%$ of males. There was no statistically significant difference between genders $(\mathrm{p}>0.05)$.

Conclusions: Expression of CT can be placed in moderate prevalence group. There was no sexual dimorphism in its occurrence in the studied group. CT can be a valuable criterion to determine differences among various populations and a significant insight into the migratory patterns in a selected geographical area.

Key Words: Carabelli's trait, Non-metric trait, Dental morphological feature, Sexual dimorphism, Maxillary molars

\section{ÖZ}

Amaç: Diş morfolojik özellikleri, filogenetik ve genetik çalışmalarda bilgi sağlamak ve ayrıca türler içinde ve türler arasında varyasyonları anlamak için yararlıdır. Karabelli tüberkülü insanlarda çeşitli derecelerde ve farklı frekanslarda tespit edildiğinden, popülasyonları karşılaştırmakta ve karakterize etmek de yararlıdır. Bu retrospektif çalı̧̧manın amacı, bir grup Türk hastada Karabelli özelliklerini (KÖ) değerlendirmektir.

Materyal ve Metod: Bu çalı̧̧mada, 14-65 yaş arası 213 hastanın (ortalama yaş 29,99 $\pm 10,04$ ), sürekli maksiller büyük azı dişleri KÖ'nin varlığına veya yokluğuna göre retrospektif olarak incelendi. Tüm veriler, IBM SPSS sürüm 22 programı (IBM SPSS, Türkiye) ve ki-kare testi kullanılarak istatistiksel olarak analiz edildi. $p<0,05$ istatistiksel olarak anlamlı kabul edildi.

Bulgular: Seçilen bir grup Türk hastada KÖ sıklı̆̆ \% 47,9 bulundu. 16/26 numaralı dişlerin herhangi birinde Karabelli görülme oranı \%46,9 iken 17/27 numaralı dişlerde bu oran \%4,2 olarak belirlendi. KÖ'nin görülme oran1 26 numaralı dişte $(\% 43,2) 16$ numaralı dişten $(\% 40,4)$ daha fazla bulundu. KÖ’nin iki taraflı olarak 16/26 numaralı dişlerde görülme oranı \%78 olarak saptand1. KÖ, kadınların \%50,7'sinde, erkeklerin ise $\% 42,9$ 'unda görüldü. Cinsiyetler arasında istatistiksel olarak anlamlı bir fark belirlenmedi $(\mathrm{p}>0,05)$.

Sonuçlar: Çalışılan grup KÖ açısından orta derece prevalans grubu içinde değerlendirilebilir. KÖ'nin oluşumu açısından cinsiyet farklılığı bulunmamaktadır. KÖ, çeşitli popülasyonlar arasındaki farklılıkları belirlemek ve seçilmiş bir coğrafi alandaki göçmen gruplar hakkında önemli bir fikir edinmek için değerli bir kriter olabilir.

Anahtar Kelimeler: Karabelli özelliği, Metrik olmayan özellik, Diş morfolojik özellik, Cinsiyet farklılıkları, Maksiller büyük azı dişleri 


\section{INTRODUCTION}

Carabelli is a tubercle, cusp, or groove usually found at the palatal surface of the mesiopalatal cusp of maxillary permanent first molars and maxillary deciduous second molars. ${ }^{1-3,4}$ It can also be detected on the maxillary permanent second and third molars, although considerably less frequently than on the first molars. ${ }^{4}$ Carabelli cusp has usually been found bilaterally. ${ }^{1,3}$ Although it was pointed out that the frequency appeared to be higher in men than in women, no significant sexual dimorphism was observed. $^{3}$

Carabelli's cusp is absent in some people. Due to numerous variations in cusp size and shape, the term Carabelli's trait (CT) is customarily used. ${ }^{5}$

The phenotypical appearance of the CT is a result of interaction between genetic and environmental factors. ${ }^{6}$ The genetic factors underlying the expression of $\mathrm{CT}$ are best represented by the upper first molars, which are used as the key teeth for population comparisons. $^{7}$

All human populations have some degree of dental morphological variation. It is commonly accepted that dental characteristics, such as size, shape, presence, number of cusps, and the size of the dental arches, are genetically determined. ${ }^{8}$

In the literature, it was found that the frequency of this structure varies from population to population. ${ }^{9-13}$ Interestingly, studies about the prevalence of CT in the Turkish population have not been reported to date. Substantially, this trait may provide a valuable criterion for racial differentiations among various populations and a significant insight into the migratory patterns of communities in a selected geographical area. Also, CT can be useful in establishing phylogenic relationships among closely related populations. ${ }^{14}$ Therefore, it would be important to investigate this trait among nations which were not previously considered. Herewith, the aim of this retrospective study was to evaluate the prevalence of CT on maxillary permanent first and second molar teeth in a group of Turkish patients.

\section{MATERIALS AND METHODS}

In this retrospective study, dental records of 420 patients referred to the Restorative Dentistry Department, Faculty of Dentistry, Istanbul Aydın University in Istanbul, Turkey from January 2014 to January 2015 were examined. The project has been reviewed and approved by the Ethical Committee of Istanbul Aydin University, Faculty of Dentistry, Istanbul (25.11.2015 and No: 073). All healthy permanent maxillary first $(16 / 26)$ and second molars (17/27) as well as the $16 / 26$ and $17 / 27$ molars that did not have dental caries or restorations were included in the study. In addition, four permanent maxillary molars that missed on any side were also eliminated. After excluding improper data, a total of 213 patients between age of 14 to 65 were evaluated according to the presence or absence of CT.

\section{Statistical analysis}

All data were statistically analyzed with the IBM SPSS version 22 program (IBM SPSS, Turkey) and the chi-squared test. $\mathrm{P}<0.05$ was considered as statistically significant.

\section{RESULTS}

A total of 213 patients ( 852 teeth) between age of 14 to 65 (mean age $29.99 \pm 10.04$ ) were examined. Of the total patients, $36.2 \%$ were males (n:77) and $63.8 \%$ were females (n:36). The male/female ratio was 1:1.77. The prevalence of CT was $47.9 \%$ for the entire studied group. The incidence of CT in any of the teeth on $\# 16 / 26$ was $46.9 \%$ and $4.2 \%$ on $\# 17 / 27$ (Table 1). 
Table 1. Prevalence of CT in the studied Turkish group

\begin{tabular}{|l|c|c|c|c|}
\hline$\#$ & Presence & Absence & Total & \% \\
\hline \hline $\mathbf{1 6 / 2 6}$ & 100 & 113 & 213 & $46.9 \%$ \\
\hline $\mathbf{1 7 / 2 7}$ & 9 & 204 & 213 & $4.2 \%$ \\
\hline
\end{tabular}

The incidence of CT was detected more on \#26 (43.2\%) than on \#16 (40.4\%) (Table 2).

Table 2. Prevalence of CT on \# 16, \# 26, \# $17, \# 27$
\begin{tabular}{|l|c|c|c|c|}
\hline$\#$ & Presence & Absence & Total & \% \\
\hline \hline $\mathbf{1 6}$ & 86 & 127 & 213 & $40.4 \%$ \\
\hline $\mathbf{2 6}$ & 92 & 121 & 213 & $43.2 \%$ \\
\hline $\mathbf{1 7}$ & 7 & 206 & 213 & $3.3 \%$ \\
\hline $\mathbf{2 7}$ & 7 & 206 & 213 & $3.3 \%$ \\
\hline
\end{tabular}

The incidence of CT on \#17 and \#27 was the same (3.3\%) (Table 2). Bilateral presence of CT on $\# 16 / 26$ was $78 \%$; on $\# 17 / 27$ was $55.6 \%$ (Table 3); and on both \#16/26/ and \#17/27 simultaneously, it was found to be $1.9 \%$ (Table 4).

Table 3. Bilateral presence of CT on \# 16/26, \# 17/27
\begin{tabular}{|l|c|c|c|}
\hline$\#$ & $\begin{array}{c}\text { Bilateral } \\
\text { presence }\end{array}$ & Total & $\%$ \\
\hline \hline $\mathbf{1 6 / 2 6}$ & 78 & 100 & $78.0 \%$ \\
\hline $\mathbf{1 7 / 2 7}$ & 5 & 9 & $55.6 \%$ \\
\hline
\end{tabular}

Table 4. Bilateral presence of CT on all molar teeth
\begin{tabular}{|l|c|c|c|}
\hline$\#$ & $\begin{array}{c}\text { Bilateral } \\
\text { presence }\end{array}$ & Total & $\%$ \\
\hline \hline $\mathbf{1 6 / 2 6}$ & 78 & 213 & $36.6 \%$ \\
\hline $\mathbf{1 7 / 2 7}$ & 5 & 213 & $2.3 \%$ \\
\hline $\mathbf{1 6 / 2 6 / 1 7 / 2 7}$ & 4 & 213 & $1.9 \%$ \\
\hline
\end{tabular}

CT was observed in $50.7 \%$ of the females and in $42.9 \%$ of the males; there was no statistically significant difference between genders ( $p$ > 0.05) (Table 5).

Table 5. Incidence of CT according to gender

Table 5. Incidence of CT according to gender
\begin{tabular}{|l|c|c|c|}
\hline \multirow{3}{*}{ CT } & \multicolumn{2}{|c|}{ Gender } & \multirow{2}{*}{$\mathbf{p}$} \\
\cline { 2 - 3 } & Female (n:136) & Male (n:77) & \multirow{2}{*}{} \\
\cline { 2 - 3 } & $\mathbf{n}(\%)$ & $\mathbf{n}(\%)$ & \\
\hline \hline Presence & $50.7 \%(\mathrm{n}: 69)$ & $42.9 \%(\mathrm{n}: 33)$ & 0.269 \\
\hline Absence & $49.3 \%(\mathrm{n}: 67)$ & $57.1 \%(\mathrm{n}: 44)$ & 0.269 \\
\hline$p>0.05$ Chi-Square test
\end{tabular}

\section{DISCUSSION}

Dental morphological traits are important because they are genetically determined, do not remodel during lifetime, and can be compared equally among different populations. ${ }^{15} \mathrm{CT}$ is one of the non-metric traits that is considered to be the most commonly occurring dental morphological feature. ${ }^{13,16}$ In European populations, the frequency of CT varies from 51 to $90 \%$, which means it is included in the moderate to high prevalence group. ${ }^{3,4}$ However, the prevalence of this trait was $0 \%$ in Eskimos, $11 \%$ in Japanese, and $21 \%$ in Chinese populations, which means it is categorized in the low prevalence group. ${ }^{4,17-19}$ The prevalence of CT in the current study was found to be $47.9 \%$ which is lower than the European incidence and higher than the Arctic and Asian countries' averages. This result can be explained as follows: Turkey is an Eurasian country with land in both Asia and Europe. ${ }^{20}$ Because it is located on two continents, it is necessary to focus on which groups the Turkish population belongs to. In 2001 Hanihara \& Ishida $^{21}$ divided the populations into six main groups (Eastern Asia, Arctic/New World, Pacific/Oceania, Central/South/West Asia, Europe, Africa) on the basis of linguistic, ethnological, and geographical backgrounds. In that study, Turkey was included in the West Asia group with two other countries (Israel and Cyprus); it was a subgroup of the Central/South/West Asia population. In another study by Hanihara ${ }^{22}$ Turkey was included in the West Asia group together with Afghanistan, Iran/Iraq, Israel, Syria/Palestine, and Cyprus. Reviewing the literature revealed that no studies have been conducted in Turkey about the prevalence of CT. Therefore, the studies previously done in the countries that were involved with the same group as Turkey should be focused on in order to correlate the presence of CT.

In one Iranian study, the cases of 500 adolescents were investigated, and the prevalence of CT was found to be $96.6 \% .{ }^{10} \mathrm{In}$ another Iranian study, 356 random cases were evaluated, and a total of 214 cases (61\%) had Carabelli's cusp. ${ }^{23}$ Although Turkish and Iranian populations were categorized in the same group, the prevalence of CT in both studies was found higher than in the present 
study. These findings can be attributed to the fact that more individuals were evaluated in those studies. Different methods used in the studies could also have produced different results.

Cyprus is another country that should be evaluated for the prevalence of CT. Evaluating the first inhabitants of Cyprus and where they originated from, it was found that the most common origins of the early immigrants were from areas where the island was viewable from the mainland, including parts of present-day Turkey and Syria. ${ }^{24}$ In 1977, Angel ${ }^{25}$ evaluated the prevalence of $\mathrm{CT}$ in Cyprus and found that the frequency varied from $0 \%$ to $0.07 \%$ on $\mathrm{M}^{2}$ and $0 \%$ to $0.37 \%$ on $\mathrm{M}^{1}$. In the same study, Syria was examined for $\mathrm{CT}$, and the frequency of this trait was found to be $0.07 \%$ on $\mathrm{M}^{2}$ and $0.32 \%$ on $\mathrm{M}^{1}$. Interestingly, the prevalence of CT in both studies was found to be lower than in the present study, even though Cyprus, Syria, and Turkey were categorized in the same population group. This can be attributed to the differences among the selected groups.

Peretz \& Smith ${ }^{26}$ evaluated the dental morphology and pathology of middle Bronze Age populations in Israel and observed the frequency of Carabelli's cusp on upper first molars. They found its incidence to be $25 \%-$ $46 \%$. The result of this study is consistent with the findings of our study.

In the literature, CT was found most frequently in first upper molars and was usually detected bilaterally. ${ }^{3,4,10,27-29}$ A correspondence between the higher prevalence of CT on 16/26 than on $17 / 27$ and bilateralism is prominent in the literature, and this was found also to be the case in our study.

Simultaneous bilateral involvement of CT on maxillary permanent first and second molars accounted for $1.9 \%$ in the present study; this was in agreement with Falomo's findings. ${ }^{9}$

In some studies, no significant sexual dimorphism was observed in the occurrence of the trait; $;^{3,9,30}$ however, in other studies, contrasting results were obtained. ${ }^{31-33}$ In the present study, no statistically significant difference was detected between genders $(p>$ 0.05 ) in terms of CT, although it was found that the trait was more frequent in females (50.7\%) than in males (42.9\%). Therefore, the results of the current study appear to confirm the suggestion made by Synder et al. ${ }^{34}$ that sexual dimorphism varies between populations.

The limitation of this study was that it was conducted in a small group of patients who applied to the faculty. Therefore, based on the results of the present study, performing a study with more patients will benefit using Carabelli trait as a valuable criterion for determining differences between diverse populations and for gaining an important insight into groups of immigrants in a selected geographical area.

\section{CONCLUSIONS}

1. The expression of CT can be placed in the moderate prevalence group.

2. There was no sexual dimorphism in its occurrence in the studied group.

3. CT can be a valuable criterion to determine differences among various populations and a significant insight into the migratory patterns in a selected geographical area.

\section{Acknowledgements}

The author wishes to thank Ebru Osmanoğlu for the assistance in statistical evaluation.

\section{Conflict of Interests}

None declared.

\section{REFERENCES}

1. Subedi N, Sah S, Chataut T, Paudel S, Pradhan A. The prevalence of the Carabelli Trait in Selected Nepalese Population. BJMMR 2015;7:285-91.

2. Kraus BS. Carabelli's anomaly of the maxillary molar teeth; Observations on Mexicans and Papago Indians and an 
Interpretation of the Inheritance. Am J Hum Genet 1951;3:348-55.

3. Alvesalo L, Nuutila M, Portin P. The cusp of Carabelli. Occurrence in first upper molars and evaluation of its heritability. Acta Odontol Scand 1975;33:191-97.

4. Sadatullah S, Odusanya SA, Mustafa A, Abdul Razak P, Abdul Wakab M, Meer Z. The prevalence of fifth cusp (Cusp of Carabelli) in the upper molars in Saudi Arabian school students. Int J Morphol 2012;30:757-60.

5. Vodanovic M, Zukanovic A, Galic I, Harvey L, Savic Pavicin I, Dumancic J, Bedic Z, Njemirovskij V, Slaus M, Brkic H. Carabelli's trait in Croatian populations over 1800 years. J Comp Hum Biol, 2013; 64:273-85.

6. Biggerstaff RH. Heritability of the Carabelli cusp in twins. J Dent Res 1973;52:40-4.

7. Scott GR, Turner CG. The anthrophology of modern human teeth. Dental morphology and its variation in recent human populations. Cambridge: Cambridge University Press, 1997.

8. Brook AH, Jernvall J, Smith RN, Hughes TE, Townsend GC. The dentition: the outcomes of morphogenesis leading to variations of tooth number, size and shape. Aust Dent $\mathbf{J}$ 2014;59:131-42.

9. Falomo OO. The cusp of Carabelli: frequency, distribution, size and clinical significance in Nigeria. West Afr $\mathrm{J}$ Med 2002;21:322-24.

10. Ramin M. Prevalence of the carabelli trait in Iranian adolescents. SRM J Res Dent Sci 2013; 4:12-5.

11.Lee GT, Goose DH. The inheritance of dental traits in a Chinese populations in the United Kingdom. J Med Genet 1972;9:336-39.

12. Shaweesh, AI. Expression of Carabelli's trait in the Jordanian population. J Stomat Occ Med 2012;5:77-82.

13.Mavrodisz K, Rozsa N, Budai M, Soos A, Pap I, Tarjan I. Prevalence of accessory tooth cusps in a contemporary and ancestral Hungarian population. Eur J Orthod 2007;29:166-69.
14. Bermudez De, Castro JM. The Carabelli trait in human prehistoric populations of Canary Islands. Biol Hum 1989;61:117-31.

15.Edgar HJ. Microevaluation of African American dental morphology. Am J Phys Anthropol 2007;132:535-44.

16.Iriarte-Diaz J. Hominid Evolution, Dental Anthropology, and Human Variation, Copyright on text and original drawings, UIC Oral Sciences Osci 590, University of Illinois Chicago, 1999.

17.Pederson PO. The east Greenland Eskimo dentition. Copenhagen, Blanco Lunos Bogtrykkeri., 1949;95-9.

18. Carbonell VM. The tubercle of Carabelli in the Kish dentition, Mesopotamia, 3000 B. C. J Dent Res 1960;39:124-28.

19. Oshima S. Dental anomalies of the Chinese. J Orient Med 1938;26:1149-150.

20.Immerfall S, Therborn G. Handbook of European Societies: Social Transformations in the 21st Century. Springer,2009. pp. 417.

21.Hanihara $T$, Ishida $H$. Os incae: variation in frequency in major human population groups. $\mathrm{J}$ Anat 2001;198:137-52.

22.Hanihara T. Morphological variation of major human populations based on nonmetric dental traits. Am J Phys Anthropol 2008;136:169-82.

23.Kaviani R Mackinejad SA, Rakhshan V, Falsafi M. Evaluating prevalence of talon and Carabelli's cusps in tooth examination of patients referred to Dental School of Islamic Azad University of Tehran: A 2-year study. J Isfahan Dent Sch 2014; 9:551-57.

24. Fox Leonard SC. Comparative health from paleopathological analysis of the human skeletal remains dating the Hellenistic and Roman periods, from Paphos, Cyprus and Corinth, Greece, 1997 (Ph.D. Thesis).

25. Angel JL. Appendix 5: Human Skeletons. In Kephala: A late neolithic settlement and cemetery, ed. JE Coleman, American School of Classical Studies, Princeton. 1977: pp 133-56.

26.Peretz B, Smith P. Dental morphology and pathology of Middle Bronze Age populations in 
Israel: Sasa and Jebel Qa'aqir. Atiqot 2004;46:45-9.

27.Hunter JP, Guatelli-Steinberg D, Weston TC, Durner R, Betsinger TK. Model of tooth morphogenesis predicts carabelli cusp expression, size, and symmetry in humans. PLoS ONE 2010;5: 11844.

28. Kamatham R, Nuvvula S. Expression of Carabelli trait in children from Southern India A cross sectional study. J Forensic Dent Sci 2014;6:51-7.

29. Shethri SA. The prevalence of the Carabelli cusp in selected Saudi population. King Saud University Journal of Dental Science 2011; 2:13-6.

30.Kieser JA. An analysis of the Carabelli trait in the mixed deciduous and permanent human dentition. Arch Oral Biol, 1984;29:403-06.

31.Agnihotri G, Singla S, Singla R. Prevalence, expression, and dichotomous nature of Carabelli's trait in permanent dentition of contemporary Jat Sikhs. SRM J Res Dent Sci 2013; 4:97-100.

32.Hsu JH, Tsai PL, Hsiao TH, Chang HP, Lin LM, Liu KM, Yu HS, Ferguson D. The effect of shovel trait on Carabelli's Trait in Taiwan Chinese and Aboriginal Populations. J Forensic Sci 1997;42:802-06.

33. Khraisat A, Taha ST, Jung RE, Hattar S, Smadi L, Al-Omari IK, Jarbawi M. Prevalence, association, and sexual dimorphism of Carabelli's molar and shovel incisor traits amongst Jordanian population. Odontostomatol Trop 2007;30:17-21.

34. Synder RG, Dahlberg AA, Snow CC, Dahlberg T. Trait analysis of the dentition of the Tarahumara Indians and Mestizos of the Sierra Madre Occidental, Mexico. Am J Phys Anthrop 1969;31:65-76.

\section{Corresponding Author}

Dr. Magrur Kazak

Bezmialem Vakif University

Dentistry Faculty

Restorative Dentistry Department

Tel : +90 5323325127

E-mail : $\underline{\text { magrur@hotmail.com }}$ 